\title{
PÚBLICO, COMUNITÁRIO E PRIVADO: DIREITOS E BEM-ESTAR NA PERSPECTIVA DO PARADIGMA COMUNITARISTA

\author{
PUBLIC, COMMUNITY AND PRIVATE: RIGHTS AND WELL-BEING FROM THE \\ PERSPECTIVE OF COMMUNITARIAN PARADIGM
}

João Pedro Schmidt*

Resumo: A cultura jurídica e política brasileira, perpassada pela dicotomia público/privado, vem legitimando arranjos institucionais e formulações legais que destacam excessivamente o papel do Estado (estatismo) e do mercado (privatismo). Tais arranjos são inadequados para a garantia dos direitos, a proteção social e o bem-estar do conjunto dos cidadãos. Em lugar do viés dicotômico, é indispensável uma nova cultura, com nova arquitetura conceitual, centrada na cooperação entre Entes Estatais, comunitários e privados. A revisitação aos conceitos de público, comunitário e privado empreendida, à luz do paradigma comunitarista, fundamenta uma abordagem inovadora em defesa da sinergia entre os setores público, privado e terceiro setor. Resta evidente a importância do terceiro setor e a indispensável participação das organizações sociais e comunitárias na garantia de direitos e na proteção social no Brasil, bem como a necessidade de planejar as políticas públicas, visando ao equilíbrio entre os setores. O método é dedutivo. A técnica de pesquisa é bibliográfica e estatística, utilizando-se dados do Cadastro Central de Empresas e do Instituto Brasileiro de Geografia e Estatística, para a caracterização dos setores econômicos.

Palavras-chave: Público. Comunitário. Privado. Terceiro setor. Comunitarismo.

\begin{abstract}
The brazilian legal and political culture, permeated by the public/private dichotomy, comes legitimizing institutional arrangements and legal formulations that overly emphasize the role of the state (statism) and market (privatism). Such arrangements are inadequate to guarantee the rights, social protection and welfare of all citizens. Instead of the dichotomous bias, is essential a new culture with a new conceptual architecture, centered on cooperation between State, community and private bodies. The revisiting the concepts of public, community and private, undertaken in the light of communitarian paradigm, underlies an innovative approach to the synergy between the public, private and nonprofit sectors. The relevance of social and community organizations is evidenced to ensure rights and social protection and the need to plan public policies aiming at a balance between the sectors. The method is deductive. The search technique is literature and statistics, using data from the Central Register of Enterprises and of the Brazilian Institute of Geography and Statistics, to characterize the economic sectors.
\end{abstract}

Keywords: Public. Community. Private. Third sector. Communitarianism.

\footnotetext{
* Doutor em Ciência Política pela Universidade Federal do Rio Grande do Sul; Mestre em Filosofia pela Universidade Federal do Rio Grande do Sul; Professor na Universidade de Santa Cruz do Sul; Avenida Independência, 2293, Universitário, 96815-900, Santa Cruz do Sul, Rio Grande do Sul, Brasil; jpedro@unisc.br
} 


\section{Introdução}

Uma universidade comunitária, mantida por organizações da sociedade civil, autogerida, e que reinveste na própria instituição todos os recursos auferidos, é comumente denominada "privada", do mesmo modo que o é uma empresa pertencente a um grupo nacional ou internacional cujos sócios se apropriam dos recursos gerados pelo negócio. A mesma palavra (privada) designa dois fenômenos completamente distintos. E essa distorção não acontece apenas no âmbito da linguagem: está expressa na legislação. Eis uma distorção comum no Brasil, associada à dicotomia público/privado, concepção dualista com profundas raízes históricas.

A alegoria de Procusto ${ }^{1}$ é metáfora aplicável a concepções como essa, ou seja, as teorias que "forçam a realidade dos fatos", que se valem de malabarismos conceituais para adequar os fatos aos esquemas teóricos. As concepções dualistas e maniqueístas insistem em explicar a vida social a partir de dois polos opostos, reduzem a complexidade sociopolítica, multifacetada e em constante transformação, à luta entre bons e maus, certos e errados, normais e anormais. O colorido terreno dos acontecimentos e das formas de organização é pintado em preto e branco. Na política, as visões maniqueístas expressam-se na ideia do confronto entre nós, os bons, contra eles, os maus.

Nesse terreno dualista desenvolvem-se as dicotomias, explicando realidades diversas com base em díades, ou seja, duplas de conceitos opostos entre si. Tratam-se de concepções simplificadoras do real, em que os fenômenos são compulsoriamente encaixados em um par de conceitos. Utilizar classificações duais não é um problema em si. O problema é reduzir a duas categorias antitéticas fenômenos complexos, os quais “[...] não aceitam reduções arbitrárias, do tipo ou é isto ou é aquilo. Tais simplificações, por não traduzirem com fidelidade o que se passa, soam como irreais, vãs tentativas de compactar, em dois blocos, uma multidão de fatos." (BRAGA NETTO, 1999, p. 13).

No campo político-jurídico, a mais clássica das dicotomias é a divisão público/privado, oriunda do pensamento grego e cujo percurso é recuperado por autores como Arendt (1993), Bobbio (2007), Habermas (1984), Sarmento (2007) e Rabotnikof (1998). A vida humana, os fenômenos sociais, as organizações e os Entes da sociedade são alinhados em dois polos: ou se é público ou se é privado. E, no mais das vezes, estatal passa a ser tomado como equivalente a público.

A dicotomia público/privado induz a erro tanto pelo que mostra quanto pelo que esconde. Seu anacronismo vem sendo denunciado a partir de diferentes ângulos. O público e o privado não são terrenos nitidamente separados, conforme mostra a ampla literatura sobre os inextricáveis vínculos entre política e economia apoiada em

\footnotetext{
1 Na mitologia grega, Procusto era um salteador de estradas que utilizava uma cama como medida para definir quem poderia seguir adiante. Ordenava a todo aquele que desejasse cruzar a estrada que se deitasse na cama, permitindo que seguisse adiante apenas aquele que tivesse a medida exata da cama. Sendo pequeno, o pretendente era esticado; sendo grande, eram-lhe cortadas as extremidades. A trajetória do salteador findou ao ser capturado por Teseu, que o prendeu em sua própria cama e lhe cortou a cabeça e os pés, aplicando-lhe o mesmo suplício que infligia às suas vítimas.
} 
Weber (1994), Polanyi (2000) e Marx e Engels (1985) e a recorrência do patrimonialismo, clientelismo e apropriação do Estado por grupos de elite assinalada por Faoro (1976) e Guilherme dos Santos (2006). O século XX registra amplos movimentos de privatização do público e de publicização do privado (BOBBIO, 2007). Há uma série de fenômenos, movimentos e organizações da sociedade civil e do terceiro setor que não apresentam características estritas nem do público estatal nem do privado (COHEN; ARATO, 2000; BRESSER PEREIRA; CUNNILL GRAU, 1999; GENRO, 1995; VIEIRA, 2001). As políticas públicas são resultados da articulação de agentes públicos, privados e sociais (PARSONS, 2003; SUBIRATS et al., 2012). É imperativo considerar as intersecções crescentes entre o público e o privado (REIS; CERQUEIRA, 2012).

A inovação teórica e conceitual tornou-se imperativa, especialmente após a crise do marxismo ao final do século XX e do ultraliberalismo no início do século XXI. Novos conceitos e abordagens ganharam espaço nas ciências sociais, as quais não se alinham à lógica dualista. É o caso das teorias da sociedade civil (BARBER, 2000; COHEN; ARATO, 2000; CANO; SIMON, 2007), do capital social (PUTNAM, 1996), da esfera pública ampliada (GENRO, 1995; VIEIRA, 2001), do welfare mix como combinação de recursos do Estado, do mercado, do terceiro setor, da família e das redes informais (GÓMEZ; BOYER, 2003). No âmbito jurídico, ampliam-se as formulações do direito fraterno (RESTA, 2004) e da justiça e mediação comunitárias (SPENGLER, 2012). Popularizaram-se conceitos inovadores como terceira via, terceiro setor, instituições híbridas, esfera pública não estatal, comunidade cívica, comunidade de políticas, governança, justiça comunitária e mediação comunitária.

Essas abordagens e conceitos inovadores requerem romper com a lógica implícita na maior parte das ciências sociais, assentada na dualidade público/privado, e a edificação de um novo paradigma, ou seja, uma concepção filosófica de fundo, que proporcione sentido inovador às diferentes partes. Várias concepções mencionadas acabam reproduzindo em certos aspectos a dualidade público/privado pela ausência de um tertius, de um terceiro polo, que designe adequadamente os fenômenos que não são estritamente públicos nem privados. É o caso de expressões na forma negativa, a exemplo de "não governamentais" e "privadas, porém públicas". Falta um conceito que designe um terceiro polo ou esfera, distinto do estatal e do privado. Esse conceito é comunitário. Em vez da díade público/privado, há de ser afirmada a tríade público/comunitário/privado.

O paradigma comunitarista Eu-Nós, explanado por Etzioni (2007, 2001a, 1999), proporciona um sentido político-filosófico abrangente a essa tríade, com base no pressuposto de que a vida em sociedade se expressa em três dimensões fundamentais e complementares: Estado, comunidade e mercado. A boa sociedade requer que esse tripé esteja em equilíbrio, quadro em que a proteção aos indivíduos e a defesa dos diretos decorre da combinação virtuosa dos mecanismos públicos, privados e comunitários. Nas sociedades ocidentais atuais, avalia Etzioni, esse equilíbrio está prejudicado pelos excessos do Estado e do mercado, e pela fragilidade das comuni- 
dades. Fortalecer o comunitário é indispensável para a construção da democracia e do desenvolvimento sustentável com inclusão social.

$\mathrm{Na}$ cultura política e jurídica brasileira continua a predominar a visão dicotômica, que se expressa na ordem legal e no aparato administrativo, sendo importantes, mas ainda de menor impacto, instrumentos que reconhecem a especificidade dos Entes da sociedade civil, a exemplo da Lei das Organizações da Sociedade Civil de Interesse Público (Lei n. 9.790/1999) e da recém-aprovada Lei das Instituições Comunitárias de Educação Superior (Lei n. 12.881/201323). Mantém-se arraigada a ideia de que ou se é público ou se é privado, um viés com especial gravidade no campo das organizações: ${ }^{4}$ as mais de cinco milhões de organizações existentes no país (IBGE, 2010) estão reduzidas, por força do Código Civil (Lei n. 10.406/2002, arts. 40 a 44), a dois tipos de pessoas jurídicas: pessoas jurídicas de direito público e pessoas jurídicas de direito privado. O terceiro setor é incluído no polo privado. Certas figuras jurídicas geradas nesse contexto suscitam a impressão de haver um malabarismo de palavras contraditórias, como a proposta das fundações estatais de direito privado (PLC 92/2007).

O imbróglio conceitual que perpassa a cultura e a legislação se mostra também na reflexão acadêmica. O grosso da literatura jurídica e das ciências sociais ignora que o comunitário é anterior ao estatal, que mesmo com a expansão do aparato estatal a participação das formas comunitárias é indispensável para suprir as necessidades das pessoas, e, que no Brasil o papel das organizações sociais e comunitárias tem sido vital ao longo da história em âmbitos como educação, saúde, assistência social e outros. Pouco destaque, por exemplo, é dado ao fato de que $46 \%$ das instituições de educação superior no Brasil têm finalidades não lucrativas, nas quais estão matriculados $35 \%$ dos universitários brasileiros (INSTITUTO NACIONAL DE ESTUDOS E PESQUISAS EDUCACIONAIS, 2012); e que 45\% das internações do Sistema Único de Saúde são feitas em hospitais filantrópicos e comunitários (CASTRO, 2012). Outras evidências são apresentadas adiante, comprovando a importância da dimensão comunitária na proteção e no bem-estar social dos cidadãos.

À luz de premissas comunitaristas ${ }^{5}$ o presente texto reconceitualiza os termos público, comunitário e privado, caracteriza os setores público, terceiro setor e

\footnotetext{
2 A Lei n. 12.881, de 12 de novembro de 2013, é fruto da mobilização das instituições comunitárias de educação superior, cuja reivindicação de um marco legal específico se traduziu na apresentação de uma proposta formulada pelas entidades representativas das comunitárias à Câmara dos Deputados, na qual foi acolhida em 2010 e aprovada em 2012. Em 2013 foi aprovada no Senado Federal, e logo após obteve a sanção presidencial.

3 Em países vizinhos, como Uruguai e Argentina, essa bipolaridade foi superada pela introdução de figuras jurídicas próprias de uma terceira categoria, como as organizaciones públicas no estatales (Argentina) e as personas públicas no estatales (Uruguai) (MALLARDI, 2007; BIASCO, 2010).

4 Utiliza-se neste texto o termo organização no sentido amplo de unidade social intencionalmente voltada a fins específicos, tanto do setor público, quanto do privado e do terceiro setor (ETZIONI, 1976, p. 10). As sociedades modernas são por excelência sociedades de organizações: todos "[...] nascemos em organizações, somos educados por organizações e quase todos nós passamos a vida a trabalhar para organizações.” (ETZIONI, 1976, p. 7). Uma expressiva parcela é criada e mantida pela sociedade civil e orienta-se por lógica própria. Enquanto o viés dualista obscurece as diferenças, o enfoque triádico favorece o reconhecimento da especificidade das organizações do terceiro setor.

5 A respeito do comunitarismo, ver o texto Comunidade e comunitarismo: considerações sobre a inovação da ordem sociopolítica (SCHMIDT, 2011).
} 
privado, e explicita a composição e a representatividade econômica desses setores no Brasil, com base em dados do IBGE.

\section{Os conceitos de público, comunitário e privado}

Público, comunitário e privado são conceitos que adquirem novo significado à luz da concepção comunitarista da complementaridade entre três esferas da vida social contemporânea: Estado, comunidade (sociedade civil) e mercado. Importa reconhecer uma terceira esfera, nem estatal e nem privada, "[...] um âmbito que nós mesmos criamos através da ação associada comum nas famílias, nos clãs, nas igrejas e nas comunidades" (BARBER, 2000, p. 12), cujo fortalecimento é essencial para a democracia.

Enquanto a díade público/privado faz sentido à luz da bipolaridade Estado/ mercado, a tríade público/comunitário/privado faz sentido à luz da tripartição Estado/comunidade/mercado. Cada "sócio" desse tripé cumpre um papel específico, que se modifica em razão das condições sociais.

Cada um é parte da solução: nenhum é tachado de ser fonte do problema. São complementares, não antagônicos. E, o que é mais importante, cada parte contribui para conseguir que as demais não ultrapassem suas funções, para assegurar que nenhuma usurpe a tarefa que pode realizar melhor que a outra. Manter esse equilíbrio se encontra no centro mesmo da boa sociedade. (ETZIONI, 2001a, p. 75).

As especificidades de cada esfera estão sintetizadas no Quadro 1.

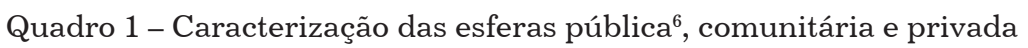

\begin{tabular}{|l|l|l|l|}
\hline & \multicolumn{1}{|c|}{ Esfera pública } & \multicolumn{1}{|c|}{ Esfera comunitária } & \multicolumn{1}{|c|}{ Esfera privada } \\
\hline Âmbito social & Estado & Comunidade/sociedade civil & Mercado \\
\hline Setor econômico & Setor público & Terceiro setor & Setor privado \\
\hline Finalidade & Bem público & Bem comum & Bem individual \\
\hline Princípios & Lei e força & Moral e costume & $\begin{array}{l}\text { Autointeresse e } \\
\text { razão individual }\end{array}$ \\
\hline Valores centrais & Legalidade e ordem & Cooperação e confiança & $\begin{array}{l}\text { Competição e } \\
\text { busca do lucro }\end{array}$ \\
\hline Poder predominante & Coercitivo & Normativo & Econômico \\
\hline Forma de gestão & Hierárquica & Autogestionária & Hierárquica \\
\hline $\begin{array}{l}\text { Organizações } \\
\text { típicas }\end{array}$ & $\begin{array}{l}\text { Órgãos públicos e em- } \\
\text { presas estatais }\end{array}$ & $\begin{array}{l}\text { Organizações da sociedade } \\
\text { civil }\end{array}$ & $\begin{array}{l}\text { Empresas e enti- } \\
\text { dades privadas }\end{array}$ \\
\hline
\end{tabular}

Fonte: adaptado de Etzioni (2007, 2001b, 2001a), Sandel (2008) e Parsons (2003).

\footnotetext{
6 A indicação do Estado como o ente próprio da esfera pública deve ser compreendida à luz da concepção aqui exposta. O público é mais amplo que o Estado; há o público estatal e o público não estatal; o comunitário equivale ao público não estatal. A tríade esfera pública/esfera comunitária/esfera privada é equivalente à esfera pública estatal/ esfera pública não estatal/esfera privada.
} 
Cabe explicitar alguns pressupostos dessa tripartição, na visão comunitarista. A primeira: Estado, comunidade e mercado são esferas necessárias à boa sociedade; todas são importantes e legítimas; explicitar diferenças não equivale a estabelecer hierarquias entre elas; a ideia do equilíbrio afasta certas ideias tradicionais à cultura jurídica e administrativista, como a taxativa supremacia do público sobre o privado; as relações Eu-Tu, próprias da vida comunitária, são prioritárias face às relações Eu-coisas, próprias do mercado, e às relações políticas, peculiares ao Estado.

A segunda: nenhuma esfera pode cumprir suficiente e adequadamente os papéis das outras; os insucessos dos regimes que privilegiaram unilateralmente o Estado ou o mercado evidenciam os limites do estatal e do privado e apontam para a importância do papel da comunidade. Esta, por sua vez, também é incapaz de realizar isoladamente as funções das demais esferas.

A terceira: nas sociedades contemporâneas, as esferas estão amplamente interligadas. O público adentra no campo do privado (publicização do privado) e o privado adentra no público (privatização do público). As políticas públicas se realizam na presença de complexas redes de agentes comunitários, estatais e privados, entrelaçamento destacado, por exemplo, pelo conceito de comunidades de políticas (policy communities). Há institutos híbridos e instrumentos de articulação entre as esferas, a partir do reconhecimento da necessidade de articulação e cooperação.

À luz desses pressupostos torna-se inteligível a conceituação a seguir exposta.

\subsection{0 público e o setor público}

Etimologicamente, público vem do latim publicus, que deriva de populicus, que designa aquilo que pertence ao populus (povo). Assim, público é o que é de todos, do povo, o que diz respeito ao coletivo. Palavras derivadas da mesma raiz evidenciam esse sentido: república é a organização política que exalta a coisa pública, o interesse comum; publicar ou publicizar é tornar algo visível a todos; publicação é o ato de tornar algo conhecido de todos; publicidade é o caráter do que é público (SILVA, 2000; SIDOU, 1995).

A res pública é a esfera dos assuntos comuns a todos, ao povo em geral. No seu sentido original, o público tem estreita relação com o comunitário, pois ambos estão na esfera dos interesses comuns, do coletivo. Cunnil Grau (1998, p. 21) assinala que a res pública, a coisa pública, concebida como coisa comum, é uma das categorias mais antigas no pensamento político e que esse é o sentido que se mantém até hoje: "O único significado que pode sobreviver do público é este", diz a autora. "De fato, suas mutações, através da teoria e da prática histórica, sedimentam-se apenas na noção de coletivo, reforçada pelo uso popular do termo: o que é de interesse ou de uso comum e, portanto, o que é visível a todos." (CUNNIL GRAU, 1998).

Enquanto as consequências de uma ação se limitam às pessoas diretamente envolvidas, a transação é privada, explica Dewey (2004); o ato se torna público quando as consequências se estendem além, afetando o bem-estar de muitos outros. A origem 
do Estado está na percepção comum a um público, ou seja, a um número amplo de indivíduos atingidos indiretamente pelas consequências da ação de outros e da necessidade de constituir meios de resolução de conflitos, por meio de medidas e normas. muitas vezes as estruturas estatais não acompanham as mudanças sociais e os novos públicos que se formam em decorrência delas. Por isso, a vida pública tem como desafio romper as formas políticas existentes: "O público que gerou as formas políticas desaparece, mas o poder, a ânsia de posse segue em mãos dos funcionários e das instituições que o público moribundo instituiu", afirma ele, e "[...] esta é a razão de que frequentemente só uma revolução consegue mudar a forma dos Estados.” (DEWEY, 2004, p. 73).

Nessa linha, o setor público (público estatal) é o conjunto de órgãos e empresas pertencentes ou controladas pelo Estado, que proporcionam bens e serviços de interesse público. Os entes desse setor estão, por definição, a serviço de todos, embora sejam frequentemente apropriados para fins particulares (patrimonialismo). É um setor de fundamental importância econômica em todas as atuais economias de mercado, mas sua sobrevalorização leva ao estatismo. O estatismo toma como equivalentes o público e o estatal e alimenta uma fé utópica na beneficência e na eficácia do Estado (EVANS, 1998, p. 53), um fenômeno relacionado ao crescimento do aparato estatal ao longo do século XX. Na maioria dos países, o Estado tornou-se o grande agente do desenvolvimento e da oferta de bens públicos, avançando largamente em campos que antes eram da esfera privada, e assumindo funções até então desempenhadas pelas comunidades. O welfare state inaugurou um estágio inédito de proteção e tutela, mas também de interferência estatal na vida dos indivíduos. Sustentadas por elevados níveis de tributação, as estruturas estatais se avantajaram para abranger um largo espectro de serviços públicos (previdência, saúde, educação, assistência social, habitação, entre outros), os encargos da intervenção na economia e a regulação social. O welfare state do século XX constituiu uma forma moderada de estatismo. Sua amplitude oscilou entre o modelo residual (liberal), no qual a intervenção do Estado é limitada às situações em que o mercado e a dinâmica familiar e comunitária se mostram insuficientes, o modelo meritocrático (corporativo), no qual a proteção estatal está direcionada a categorias profissionais, e o modelo redistributivo, que proporciona amplos benefícios com caráter universalista (ESPING-ANDERSEN, 1995). A forma extremada de estatismo foi a dos regimes socialistas do século XX, com níveis inéditos de estatização da economia, forte controle da vida social e repressão a qualquer forma de dissenso. No Brasil, o estatismo apresentou-se noutro formato, relativamente moderado: o modelo nacional-desenvolvimentista construído a partir dos anos 1930, centrado no papel indutor do Estado no desenvolvimento econômico, protagonista do processo de industrialização e responsável pela gradativa oferta de bens, serviços e proteção social.

A concepção estatista está defasada conceitualmente e superada pelos fatos. Com a crise dos modelos tradicionais da democracia representativa, processaram-se mudanças importantes na esfera pública, que passou a englobar organizações e atores não estatais. Conselhos gestores de políticas públicas, orçamentos participativos, conselhos regionais e municipais, conferências setoriais, câmaras temáticas, fóruns 
de debates, bem como a ação das instituições comunitárias, das entidades sem fins lucrativos e das ONGs são inovações que não cabem dentro da velha roupagem estatista. A superação do estatismo nada tem a ver com menosprezo do público ou do papel do Estado, mas com a limitação dos excessos intervencionistas e a construção de ações sinérgicas com a comunidade e o mercado.

\subsection{0 privado e o setor privado}

O termo privado refere-se ao indivíduo, à família ou ao pequeno grupo. É sinônimo de particular, distinto tanto do público quanto do comunitário, que estão na esfera do comum, do coletivo. Etimologicamente, “[...] a palavra privus (particular) originou duas variantes, privatus (privado) e privus-lex ou privilegium (lei para um particular, privilégio)." (ALENCASTRO, 1997, p. 16). Termos correlatos reforçam o sentido original: privativo é o que é de uso ou prerrogativa particular; privacidade é a característica da vida privada do indivíduo; privatizar é transformar uma empresa pública em privada.

O território do privado nas sociedades modernas é a família e o mercado. Os grandes debates econômicos sobre o privado referem-se aos sistemas de mercado. $\mathrm{O}$ sistema de mercado caracteriza-se, conforme Lindblom (2002), por coordenar as atividades e os comportamentos humanos mediante interações mútuas entre compradores e vendedores, em lugar de uma autoridade central. Nos sistemas de mercado, os agentes privados têm como finalidade o bem individual, agem em razão do lucro, proclamam a competição e a livre iniciativa, como valores centrais, e reconhecem o poder econômico como predominante; a profissionalização do corpo de trabalhadores é própria da estrutura administrativa das empresas, cuja gestão obedece a padrões hierárquicos e os indivíduos têm acesso a elas por meio de seleção profissional.

Há uma percepção equivocada de que nos sistemas de mercado os indivíduos agem livremente, cada um seguindo seu próprio caminho, de modo que a iniciativa privada seja uma ação individualizada e voluntária de cada qual. O que ocorre, na verdade, segundo Lindblom (2002, p. 20), é que os indivíduos “[...] se encontram ligados mutuamente na perseguição de seus objetivos através de suas interações nos mercados." Assim, o sistema de mercado atual nada tem a ver com laissez faire ou com Estado mínimo. O Estado é um ator fundamental do mercado e o terceiro setor também tem atuação importante. A atuação estatal é particularmente influente: o Estado é o principal comprador, é um ofertante de bens e serviços em larga escala, proíbe ou restringe vendas, subvenciona a maioria das empresas que não controla diretamente, é um poderoso agente de oferta de crédito e dinheiro, organiza fundos e os distribui por meio de programas de bem-estar. Portanto, o mercado de nossos dias é o território privilegiado do privado, mas a livre iniciativa sem restrições não passa de ficção.

O setor privado compreende o conjunto das empresas e organizações privadas que se caracterizam pela apropriação individual do lucro. O caráter privado apenas 
se aplica às organizações que preenchem dois requisitos: visam lucro e permitem sua apropriação pelo proprietário.

Em outras palavras: o que distingue o setor privado não é a busca do lucro, entendido como superávit (resultado econômico do empreendimento). A busca de superávit é própria também das empresas estatais e das entidades do terceiro setor. O que caracteriza o setor privado é a apropriação individual ou particular do lucro, o usufruto do resultado produzido pela empresa por parte do proprietário. Todas as organizações que permitem a apropriação do lucro para fins pessoais pertencem ao setor privado. No reino mercantil não há nenhum impedimento para que o superávit seja aproveitado pelo dono da empresa da maneira que preferir, possibilidade que motiva o empresário a arriscar seu capital em novos empreendimentos.

A iniciativa privada e o apetite pelo lucro não são um mal para a sociedade, mas requerem limites. O autointeresse é próprio da natureza humana e a ele estão associadas poderosas energias e a capacidade criativa dos indivíduos. A liberação das energias individuais das amarras impostas pelo modo de produção feudal foi um dos principais ingredientes do crescimento econômico a partir da Revolução Industrial e do desenvolvimento tecnológico em níveis inéditos na história humana. Sachs (2005) ressalta a rapidez e a grandeza da prosperidade econômica dos últimos dois séculos, que comprovam o sucesso da economia de mercado em termos de renda, riqueza e avanço tecnológico. Há 200 anos praticamente todos eram pobres, à exceção de uma minoria de governantes e proprietários de terra, e não havia grandes divisões entre ricos e pobres nos diferentes continentes. Nos dois últimos séculos, tanto a população quanto a renda dispararam. O produto mundial bruto aumentou 49 vezes. A renda per capita cresceu nove vezes no mundo. Sachs (2005) assinala que esse crescimento foi altamente desigual, levando a um grande fosso entre regiões ricas e pobres, o que se deveu em parte à apropriação de riquezas dos países pobres por parte dos países ricos, mas especialmente à difusão das modernas tecnologias nas regiões desenvolvidas.

Etzioni (2007) salienta que os indivíduos enquanto agentes econômicos no mercado não estão apartados da cultura e da vida social. O mercado não é uma esfera separada e independente da sociedade: ele está imerso em uma cápsula social, a sociedade, da qual é um subsistema. As transações que acontecem no mercado e as formas de competição entre os agentes e grupos econômicos são influenciadas fortemente pelos valores dominantes na sociedade. A competição é uma forma de conflito oriunda de interesses e objetivos divergentes dos indivíduos, que postos juntos nunca constituem um conjunto harmonioso. Por isso, são requeridos mecanismos para controlar e proteger a competição, pois deixada a si pode chegar à autodestruição. $\mathrm{O}$ contexto social não apenas restringe, mas é uma precondição para o funcionamento da competição. A competição adequadamente limitada é uma força construtiva; a competição desatada é destrutiva; a competição reprimida perde seu poder criativo.

Se a relevância econômica da iniciativa privada e do mercado é indiscutível, do ponto de vista dos valores, o mercado é uma esfera pobre. O mercado é o reino das relações instrumentais, das relações Eu-coisas, do enaltecimento do egoísmo e 
do consumo fácil. Mas a prevalência dos valores mercantis mostrou-se crescente nas décadas da euforia neoliberal e do triunfalismo do mercado. Sandel (2012, p. 16) faz uma admoestação severa sobre os limites morais do mercado: nas últimas décadas "[...] fomos resvalando da situação de ter uma economia de mercado para a de ser uma sociedade de mercado." Cita como exemplos preocupantes escolas, hospitais, prisões e serviços de segurança orientados por critérios de lucro; a terceirização da guerra e da gravidez; a venda do direito de poluir; os sistemas de financiamento eleitoral; a utilização do próprio corpo para anúncios publicitários; o comércio de órgãos humanos, entre muitos outros. Para o autor, quando decidimos que certos bens podem ser comprados e vendidos, decidimos implicitamente que são tratados como mercadorias; mas muitos bens, a começar pelos seres humanos, não podem ser tratados dessa maneira. A crise financeira de 2008 revelou os limites econômicos e sociais do mercado, mas não aconteceu o devido debate público sobre os limites do mercado, de modo que a confiança nele não diminuiu de modo geral.

O exame dos excessos do mercado exige uma análise do direito e dos limites da privacidade, tema que acompanha a afirmação da noção de indivíduo no pensamento moderno. Incensada pelo liberalismo, a privacidade é alvo da crítica feminista, que denuncia a violência e os abusos cometidos ao abrigo da privacidade (PATEMAN, 1996; RABOTNIKOF, 1998). Os comunitaristas responsivos avaliam que a concepção que se consolidou nas décadas recentes é de uma privacidade despreocupada com o bem comum. Para Etzioni (2012), os individualistas tratam a privacidade como algo sagrado, intocável, uma esfera dissociada do exame das condições sociais que possibilitam os direitos individuais, a qual precisa ser constantemente defendida dos ataques do Grande Irmão (Estado). Para ele, é preciso afirmar um conceito equilibrado de privacidade, combinando autonomia individual e comunidade, direitos e responsabilidades. Privacidade é um direito fundamental do indivíduo, mas está associada a responsabilidades correspondentes. A privacidade, nas palavras de Etzioni (2012, p. 306), é "[...] uma licença social que exime uma categoria de atos, incluindo pensamentos e emoções, do escrutínio comunitário, público e governamental", uma isenção vinculada aos costumes sociais e às leis vigentes. A isenção de escrutínio de certos atos individuais, própria da privacidade, contém implicitamente a noção de barreiras legítimas e ilegítimas. A privacidade não é, portanto, uma esfera sagrada, afastada, ou acima das questões sociais, mas uma esfera que reflete os valores particulares de uma sociedade. Em contextos excessivamente individualistas, é preciso reequilibrar a concepção de privacidade por meio do reforço das preocupações com o bem comum, ao passo que em contextos excessivamente coletivistas há que reforçar o respeito ao espaço pessoal de cada qual. ${ }^{7}$

\footnotetext{
$\mathrm{Na}$ ordem jurídica brasileira, o direito à privacidade é bem protegido, estando previsto na Constituição - o art. $5^{\circ}$, inc. X, estabelece a inviolabilidade da intimidade, da vida privada, da honra e da imagem das pessoas, assegurado o direito à indenização pelo dano material ou moral decorrente de sua violação - e no Novo Código Civil (Lei n. 10.406/2002) - que trata dos direitos da personalidade nos arts. 11 a 21.
} 


\subsection{0 comunitário e o terceiro setor}

Comunitário deriva do latim communis (comum) e communitas (comunidade). Comunidade designa a forma de vida social caracterizada por relações personalizadas, de coesão social, de compromisso moral e de continuidade no tempo, distinta das formas marcadas pela impessoalidade, anonimato e contratualidade, denominadas na sociologia de sociedade ou associação. Comunitário diz respeito ao que é comum a um coletivo; é o terreno do bem comum. Por isso a proximidade do comunitário com o público: ambos referem-se àquilo que é comum a uma coletividade.

Tema ancestral, comunidade é para muitos um conceito vago e impreciso. Etzioni (2001b) contrapõe aos críticos uma definição precisa: as comunidades se distinguem por relações de afeto e pelo compartilhamento de valores e significados.

\footnotetext{
Comunidade é uma combinação de dois elementos: (a) Uma rede de relações carregadas de afeto entre um grupo de indivíduos, relações que frequentemente se cruzam e se reforçam umas às outras (em vez de tão somente relações individuais, uma a uma ou encadeadas). (b) Uma medida de compromisso com um conjunto de valores compartilhados, normas e significados, e uma história e identidade compartilhadas - em resumo, com uma cultura particular. (ETZIONI, 2001b, p. 142-143).
}

Viver em comunidade não é o mesmo que estar juntos. Dewey (2004) mostra que a associação, na acepção de estar juntos, é uma lei da vida humana: todos os seres humanos atuam juntos em tudo o que fazem; nada há que seja estritamente individual. Estar juntos é um fato indiscutível e não tem sentido perguntar como os indivíduos chegam a se associar. A questão que merece análise é como as comunidades humanas adquirem traços tão diferentes dos demais seres da terra e do universo. Dewey (2004) entende que as características singulares das comunidades humanas têm sua raiz na observação que os humanos fazem da sua ação conjunta: observar os efeitos da ação conjunta leva os homens a refletir sobre sua própria conexão, tornando-a objeto de atenção e interesse. A observação muda a condição de estar juntos, leva as pessoas a pensarem nas consequências de sua conduta sobre os demais e na conduta dos demais sobre si próprios. É o que acontece ao longo da vida de cada pessoa: com o amadurecimento, criamos consciência das consequências da conduta individual e grupal na vida social. Essa consciência é a base da moral, premissa da vida em comunidade. Enquanto a associação é física e orgânica, "[...] a vida comunitária é moral, deve sustentar-se emocional, intelectual e conscientemente." (DEWEY, 2004, p. 139).

As comunidades são historicamente anteriores ao Estado e ao mercado. Aldeias, tribos, clãs, guildas, cidades, comunas, mosteiros, burgos, condados e distritos constituem algumas das formas comunitárias das sociedades antigas e medievais, vitais para a compreensão da sua dinâmica econômica, política e social. Séculos antes do welfare state, a proteção social, a saúde, a educação, a administração da justiça, 
a organização do trabalho e outros aspectos fundamentais para a vida em sociedade estiveram aos cuidados de comunidades e organizações comunitárias.

A Revolução Industrial e a racionalidade moderna foram, em um primeiro momento, radicais adversários das comunidades tradicionais. Nos séculos XVII e XVIII, lembra Nisbet (1998), proliferaram os ideais individualistas do homem livre por natureza, vinculado racionalmente e de modo limitado a outros homens por volição e consentimento, ideais que se opunham frontalmente à ética e à vida comunitária. O Iluminismo votou oposição irrestrita a todas as formas de associação tradicional e comunitária. Os laços comunitários medievais foram percebidos como obstáculos ao progresso capitalista. As reformas legislativas miravam "[...] a persistência das tradições comunais que haviam ultrapassado seu tempo de vida útil e constituíam um impedimento ao desenvolvimento econômico e à reforma administrativa." (NISBET, 1998, p. 258). O século XIX presenciou uma reviravolta nesse quadro: houve uma redescoberta da comunidade, com forte impacto no pensamento filosófico, histórico e sociológico. Comunalismo deixou de ser sinônimo de obscurantismo e a importância dos ideais comunitários foi retomada por muitos pensadores e doutrinadores. O movimento operário e socialista impulsionou uma série de experiências comunitárias importantes: o movimento cooperativista internacional; a experiência comunitária da cidade italiana de Ivrea, liderada por Adriano Olivetti; as comunidades de trabalho francesas; as cooperativas de produção suecas; as comissões de fábrica alemãs; os kibbutzin israelenses; e as variadas comunidades utópicas na Inglaterra, nos Estados Unidos e em diversas partes do mundo (SCHMIDT, 2011).

A expansão do welfare state teve como um de seus efeitos a absorção de muitas atividades comunitárias: proteção social, saúde, educação, administração da justiça, disciplinamento das relações de trabalho, entre outras, passou-se a constituir funções estatais, avançando em searas que anteriormente eram próprias das famílias e das comunidades. No entanto, isso não significou a extinção dos corpos sociais intermediários, que foram mais duramente atingidos nos regimes socialistas. A constituição de uma robusta sociedade civil e o crescimento do chamado terceiro setor em grande parte dos países ocidentais na segunda metade do século XX evidenciou que os organismos comunitários, criados e mantidos pela sociedade civil, são insubstituíveis em múltiplas funções sociais.

O conjunto das organizações da sociedade civil é denominado usualmente terceiro setor, setor não lucrativo e setor do voluntariado. Opta-se aqui pelo termo terceiro setor, pela sua adequação à lógica triádica, estabelecendo a seguinte acepção: conjunto de organizações criadas e mantidas pela sociedade civil (ou comunidade), que proporciona bens e serviços de interesse comum e cujos resultados são apropriados coletivamente. ${ }^{8}$ Autogestionárias, a apropriação coletiva dos resultados das organizações é feita mediante reinvestimento na própria atividade (associações, fundações)

8 Sobre o conceito de terceiro setor, ver Gómez e Boyer (2003, cap. 5). 
ou pela socialização dos resultados entre seus membros (cooperativas). Esse setor abrange as organizações formalmente constituídas - associações e fundações comunitárias, organizações não governamentais, cooperativas, sindicatos, entre outros bem como as redes informais de comunidades culturais, religiosas, profissionais, políticas, étnicas, de gênero e outras.

A acepção de terceiro setor aqui proposta - mais ampla que a das formulações usuais na literatura ${ }^{9}$ e na legislação - é coerente com o emprego do modelo triádico. Recapitulando: o que distingue o setor público? A pertença ao Estado e os fins públicos. O que caracteriza o setor privado? Os fins individuais e a apropriação privada do lucro. E o que especifica o terceiro setor? A pertença à sociedade, a finalidade comum e a apropriação coletiva dos resultados.

É importante uma breve digressão sobre as expressões sem fins lucrativos e fins não econômicos, com as quais se designa usualmente o terceiro setor. Ambas são imprecisas. Considerando o lucro como sinônimo de ganho ou superávit, ${ }^{10}$ é indiscutível que o superávit é almejado não apenas pelas empresas privadas, mas também pelas empresas estatais e por muitas organizações do terceiro setor, pelo simples fato de que o resultado econômico positivo é requisito para a mantença, a evolução e o aperfeiçoamento de qualquer organização autossustentável. Buscar superávit em nada denigre uma organização do terceiro setor; a apropriação individual do superávit é que se choca com os fins do terceiro setor. O termo fins não econômicos, introduzido pelo Código Civil de 2002, dá margem ao mesmo equívoco, de que o terceiro setor não precisa assumir a preocupação da sustentação econômica, de que é sustentado economicamente por outrem. Com isso, exclui-se o importante contingente das instituições que se autossustentam por meio da prestação de serviços, e reduz-se o terceiro setor ao conjunto das organizações que dependem de recursos destinados pelos setores público e privado. Ou seja, se por um lado os termos sem fins lucrativos e fins não econômicos indicam que tais organizações não têm como finalidade a geração de lucro ou a busca de resultados econômicos, estando orientadas à consecução de finalidades sociais, ambientais, culturais, etc., por outro contribuem para a criação dos mal-entendidos já citados. O termo organizações comunitárias é bem mais apropriado para indicar a característica essencial do terceiro setor: o que distingue uma organização do terceiro setor de um Ente Público é que o primeiro é criado e sustentado pela comunidade e o outro pelo Estado; e o que distingue uma organização do terceiro setor de uma empresa privada é que naquela todo o resultado econômico é reinvestido na

\footnotetext{
$9 \quad$ Entre os importantes levantamentos no Brasil sobre as entidades sem fins lucrativos cabe mencionar os estudos sobre as Fundações Privadas e Associações sem Fins Lucrativos no Brasil (IBGE, IPEA, ABONG e GIFE), realizados desde 2002, que compreendem aquelas que atendem, simultaneamente, aos critérios de serem "privadas, sem fins lucrativos, institucionalizadas, autoadministradas e voluntárias". Não há uma metodologia unificada nos estudos internacionais para mensurar o terceiro setor, cabendo mencionar os conhecidos estudos do pesquisador norteamericano Lester Salamon, professor da Johns Hopkins University.

10 Segundo o Novo Dicionário Jurídico de Brasileiro, lucro equivale a interesse, proveito, ganho. "Podemos definir o lucro como o proveito econômico auferido em uma operação comercial ou especulativa.” (NÁUFEL, 2008, p. 218).
} 
própria atividade ou socializado entre os membros, enquanto nesta o proprietário pode destinar, legítima e legalmente, o lucro obtido no negócio para onde quiser. ${ }^{11}$

O conceito ampliado de terceiro setor aqui empregado inclui uma série de organizações e instituições que usualmente são caracterizadas como privadas.

É o caso das universidades comunitárias, dos hospitais comunitários, das cooperativas e das entidades sindicais, entre outros. As universidades e hospitais comunitários, criados e mantidos pela sociedade civil, são carimbados de privados em razão de uma legislação inadequada, mas também pelo fato de cobrarem os serviços não remunerados pelo Estado, como se fosse possível proporcionar tais serviços sem uma receita correspondente. As cooperativas são consideradas privadas por serem lucrativas, já que repartem resultados econômicos entre seus membros. Esse entendimento é inaceitável do ponto de vista comunitarista: as cooperativas são uma das principais formas de realização dos ideais comunitários; a socialização dos resultados não é negação, mas a expressão da realização de valores comuns (CHACON, 1959; BUBER, 2006). Isso também se aplica aos sindicatos, instrumentos históricos de luta dos trabalhadores por melhores condições de trabalho e de remuneração. A luta pelos interesses coletivos dos trabalhadores evidencia sua identidade comunitária e justifica sua inclusão nesse setor.

Há outras instituições e organizações que ficam mais bem situadas no terceiro setor do que no setor público ou privado. É o caso da maioria dos clubes esportivos. Por que são considerados privados? No caso dos clubes profissionais, um entendimento comum é que são espaços de lucrativos negócios e que cada vez mais utilizam modelos de gestão empresarial. Mas esse argumento não se sustenta diante do fato de que as grandes empresas estatais operam com negócios de muito maior envergadura e seus gestores são tão "empresariais" quanto os da iniciativa privada. A maioria dos clubes esportivos não tem proprietários individuais, suas direções são eleitas por conselhos ou pelos associados, o patrimônio do clube é coletivo e os resultados obtidos são reinvestidos no esporte. Por isso, as agremiações esportivas (excluídas as que pertencem a empresários) enquadram-se nas características do terceiro setor.

E os partidos políticos? Tratam-se de organizações da sociedade que estão próximas do aparelho de Estado, mas não o integram. Por outro, embora as análises orientadas pela abordagem do "mercado político" evidenciem ser comum que partidos se orientem por critérios mercantis, considerá-los organizações do mercado é uma extrapolação indevida. Na condição de entidades voltadas ao exercício da política, cuja finalidade é a conquista do poder, voluntárias, autogeridas, constituídas por cidadãos com afinidades políticas, os partidos têm mais em comum com o terceiro setor do que com o setor público ou privado.

\footnotetext{
11 A expressão sem fins lucrativos está presente na Constituição Federal. O Código Civil de 2002 (Lei n. 10.406/2002) emprega, em seu lugar, a expressão fins não econômicos, questionável pelos mesmos motivos: sugere que as organizações sociais estão despreocupadas em relação à autossustentabilidade econômica.
} 
A importância da comunidade e do terceiro setor ultrapassa a dimensão dos serviços prestados. Trata-se da esfera em que se constroem e reconstroem os valores e as relações mais importantes da vida em sociedade, as relações Eu-Tu e Eu-Nós (BUBER, 2006; ETZIONI, 2001a). Embora nem todas as organizações do terceiro setor sejam autênticos espaços de vida comunitária, é esse setor o terreno mais fértil para a proximidade afetiva e o compartilhamento e a recriação de valores morais. Seu fortalecimento é indispensável para a boa sociedade.

\section{Setor público estatal, setor privado e terceiro setor no Brasil}

A mais completa fonte de informações sobre organizações formais (órgãos públicos, empresas e entidades) no país é o Cadastro Central de Empresas (Cempre), do IBGE. O Cadastro de 2010 informa que há no país 5,1 milhões de organizações, com 49,7 milhões de pessoas ocupadas, sendo 43 milhões na condição de assalariados e 6,7 milhões na condição de sócios ou proprietários, cujo conjunto importa no pagamento de salários e outras remunerações na ordem de $\mathrm{R} \$ 908$ bilhões.

Em vista de o ordenamento das organizações adotado pelo IBGE não coincidir com os critérios aqui adotados, recorreu-se ao Instituto ${ }^{12}$ para obter informações por tipo de organização, o que tornou possível dimensionar os setores público, privado e terceiro setor de acordo com a conceituação exposta neste texto.

Cabe ressaltar que essas estatísticas se referem apenas às organizações formais, que contemplam o conjunto do setor público (no qual se pressupõe que não haja informalidade), mas de forma parcial o setor privado e o terceiro setor, nos quais parte importante das organizações não é formalizada nem consta em registros oficiais.

\subsection{Setor público no Brasil}

O setor público (estatal) brasileiro, segundo o Cempre (2010), é composto por 19.956 órgãos públicos e empresas estatais, nos níveis federal, estadual e municipal, com 10.005.817 pessoas ocupadas e remuneração total de $\mathrm{R} \$ 326.691 .854 .000,00$. É o segundo setor em importância econômica do país.

A Tabela 1 mostra a composição do setor público brasileiro, incluídas as empresas estatais. A ausência de informações em alguns casos sobre pessoal ocupado e remuneração, nesta e nas próximas tabelas, acontece quando há poucas unidades envolvidas e segue o procedimento de desidentificação adotado pelo IBGE nesses casos. Assim, o total de pessoal ocupado e de remuneração está levemente subdimensionado nos três setores, sem prejudicar a argumentação no seu todo.

$\overline{12} \mathrm{O}$ autor agradece o gentil atendimento dispensado pelos servidores Sidnéia Reis Cardoso, Bruno Erbisti Garcia e Neimar Rodrigues Guimarães, da Diretoria de Pesquisas do IBGE, para a obtenção dos dados aqui apresentados. 
Tabela 1 - Setor público no Brasil: órgãos e empresas, pessoal ocupado e remunerações

\begin{tabular}{|c|c|c|c|}
\hline Órgãos e entidades empresariais & $\begin{array}{l}\text { N. de órgãos e } \\
\text { empresas }\end{array}$ & $\begin{array}{l}\text { Pessoal } \\
\text { ocupado }\end{array}$ & $\begin{array}{l}\text { Salários e remune- } \\
\text { rações (em } 1.000 \text { R } \$)\end{array}$ \\
\hline $\begin{array}{l}\text { Órgão Público do Poder Executivo } \\
\text { Federal }\end{array}$ & 461 & 469.425 & 29.616 .361 \\
\hline $\begin{array}{l}\text { Órgão Público do Poder Executivo Esta- } \\
\text { dual ou Distrito Federal }\end{array}$ & 950 & 2.679 .269 & 82.642 .756 \\
\hline $\begin{array}{l}\text { Órgão Público do Poder Executivo } \\
\text { Municipal }\end{array}$ & 7.108 & 4.673 .949 & 86.881 .097 \\
\hline $\begin{array}{l}\text { Órgão Público do Poder Legislativo } \\
\text { Federal }\end{array}$ & 5 & $\mathrm{x}$ & $\mathrm{x}$ \\
\hline $\begin{array}{l}\text { Órgão Público do Poder Legislativo } \\
\text { Estadual ou Distrito Federal }\end{array}$ & 64 & 71.491 & 5.125 .405 \\
\hline $\begin{array}{l}\text { Órgão Público do Poder Legislativo } \\
\text { Municipal }\end{array}$ & 4.947 & 95.181 & 3.124 .750 \\
\hline $\begin{array}{l}\text { Órgão Público do Poder Judiciário } \\
\text { Federal }\end{array}$ & 102 & 121.515 & 15.318 .812 \\
\hline $\begin{array}{l}\text { Órgão Público do Poder Judiciário } \\
\text { Estadual }\end{array}$ & 151 & 171.777 & 14.017.373 \\
\hline Autarquia Federal & 580 & 253.778 & 17.856 .151 \\
\hline $\begin{array}{l}\text { Autarquia Estadual ou do Distrito } \\
\text { Federal }\end{array}$ & 348 & 225.101 & 9.667 .956 \\
\hline Autarquia Municipal & 1.357 & 92.898 & 2.224 .366 \\
\hline Fundação Federal & 51 & 79.970 & 6.293 .818 \\
\hline $\begin{array}{l}\text { Fundação Estadual ou do Distrito } \\
\text { Federal }\end{array}$ & 207 & 108.888 & 3.814 .148 \\
\hline Fundação Municipal & 761 & 66.587 & 1.621 .224 \\
\hline Órgão Público Autônomo Federal & 2 & $\mathrm{x}$ & $\mathrm{x}$ \\
\hline $\begin{array}{l}\text { Órgão Público Autônomo Estadual ou } \\
\text { do Distrito Federal }\end{array}$ & 40 & 10.041 & 1.469.313 \\
\hline Órgão Público Autônomo Municipal & 126 & 1.177 & 15.401 \\
\hline Fundo Público & 1.468 & 112.194 & 1.891 .608 \\
\hline Associação Pública & 357 & 4.347 & 100.220 \\
\hline Empresa Pública ${ }^{13}$ & 356 & 346.043 & 16.926.518 \\
\hline Sociedade de Economia Mista ${ }^{14}$ & 333 & 420.560 & 28.015.347 \\
\hline Representação Diplomática Estrangeira & 182 & 1.626 & 69.230 \\
\hline Total & 19.956 & 10.005 .817 & 326.691 .854 \\
\hline
\end{tabular}

Fonte: IBGE (2010).

Esses números indicam que o setor público brasileiro tem baixa representatividade em termos do número de órgãos e empresas, mas tem expressivo peso em termos de pessoal ocupado e de salários e remunerações.

Um estudo do Instituto de Pesquisa Econômica e Aplicada (2010) acrescenta um importante dado ao destacar a mudança na distribuição dos empregos nas esferas de governo nas últimas décadas, com forte aumento do peso do emprego da es-

\footnotetext{
${ }^{13}$ Empresa pública é a entidade empresarial, com personalidade jurídica de direito privado e participação única do Poder Público no seu capital e direção, na forma da lei, sendo de propriedade única do Estado.

${ }^{14}$ Sociedade de economia mista é a entidade dotada de personalidade jurídica de direito privado, criada por lei para o exercício de atividade econômica, sob a forma de sociedade anônima, cujas ações com direito a voto pertençam em sua maioria ao Poder Público.
} 
fera municipal: em 1950, os municípios contribuíam com $12 \%$ dos ocupados do setor público, e, atualmente, sua participação é de 50\%; os empregos do âmbito estadual mantêm-se nesse período em aproximadamente 35\%; os do âmbito federal caíram de 55 para cerca de $15 \%$. Sobre o crescimento do emprego público no Brasil nos anos recentes, os analistas do IPEA avaliam que está associado ao desenvolvimento econômico, à urbanização e à democratização, fatores que requerem mais serviços públicos. Na comparação com países desenvolvidos e mesmo da América Latina, o emprego público no Brasil é proporcionalmente menor, não se sustentando o alegado "inchaço da máquina pública", pauta frequente da mídia nacional.

Outro estudo (MACIEL; ARVATE, 2010) sustenta que o tamanho do Governo Federal no Brasil se manteve estável, do ponto de vista econômico, nas últimas décadas: entre 1980 e 2005, a envergadura do Governo Federal, calculada com base nas despesas de custeio da administração federal e do custeio das empresas estatais, ficou na faixa de $20 \%$ do PIB, independente das mudanças, ajustes e privatizações. Segundo os autores, constatou-se crescimento das despesas de custeio da administração federal e queda das despesas de custeio das estatais produtivas.

Quanto às empresas estatais, a Tabela 1 informa a existência de 356 empresas públicas, com 346.043 empregados, e 333 sociedades de economia mista, com 420.560 empregados, em um total de 689 empresas, totalizando 766.603 empregados. Destas, 134 empresas são federais, as quais empregam 497 mil funcionários e cujos investimentos devem superar os R $\$ 100$ bilhões em 2012, conforme o Ministério do Planejamento, Orçamento e Gestão (BRASIL, 2011). As empresas estatais vêm sendo objeto de forte controvérsia. Reconhecidas por uns como um dos principais mecanismos de desenvolvimento do país desde a década de 1930 e por outros como excessiva interferência estatal na economia, foram alvo de privatização na década de 1990, nos Governos Collor de Melo, Itamar Franco e Fernando Henrique Cardoso: 110 empresas federais e 28 estaduais foram privatizadas, com arrecadação de recursos da ordem de U\$ 105 bilhões aos cofres públicos. Segundo Gobetti (2010), essa medida se mostrou completamente ineficaz para reduzir o endividamento público e não alavancou o crescimento econômico do país. ${ }^{15}$ Com a interrupção do processo de privatização a partir do Governo Lula, as estatais se tornaram elemento importante da nova política econômica e da retomada do crescimento, com resultados crescentemente positivos nos últimos anos e exercendo um importante papel na melhoria da situação das finanças públicas. Para o autor, somente no período de 1999 a 2006 a contribuição das estatais para o ajuste fiscal totalizou "[...] cerca de $R \$ 254$ bilhões ou US $\$ 90$ bilhões, pouco mais do que a receita obtida entre 1991 e 2002 com o programa de privatização." (GOBETTI, 2010, p. 44).

Com a ressalva de que a influência econômica do Estado vai muito além dos limites do setor público, ${ }^{16}$ é sustentável a posição de que o equilíbrio Estado-comu-

\footnotetext{
$\overline{15}$ A lista das empresas privatizadas desde 1990 se encontra em: <http://www.planejamento.gov.br/secretarias/upload/Arquivos/dest/estatistica/UnivEst_privatizadas.pdf $>$. Acesso em: 10 jul. 2012.

16 Lazzarini (2011) argumenta que as privatizações não reduziram o peso do Estado brasileiro. Segundo o autor, o mundo corporativo pós-privatizações e pós-abertura das bolsas de valores mantém e aprofunda o capitalismo de
} 
nidade-mercado no Brasil não requer a redução do setor público, mas medidas que o coloquem efetivamente a serviço do conjunto da população.

\subsection{Setor privado no Brasil}

O setor privado brasileiro é o maior setor econômico do país, constituído por um conjunto de 4.596.417 empresas e organizações privadas, com 36.169.019 pessoas ocupadas, e remuneração total de $\mathrm{R} \$ 515.604 .312 .000,00$. A Tabela 2 detalha as informações segundo o tipo de empresa.

Tabela 2 - Setor privado no Brasil: empresas, pessoal ocupado e remunerações

\begin{tabular}{|c|c|c|c|}
\hline Tipo de empresa ${ }^{17}$ & N. de empresas & $\begin{array}{l}\text { Pessoal } \\
\text { ocupado }\end{array}$ & $\begin{array}{c}\text { Salários e } \\
\text { remunerações } \\
(\text { em } 1.000 \text { R } \$)\end{array}$ \\
\hline Sociedade Anônima Aberta & 934 & 1.081 .533 & 38.206 .423 \\
\hline Sociedade Anônima Fechada & 19.643 & 3.955 .728 & 107.379.056 \\
\hline Sociedade Empresária Limitada & 2.474 .257 & 24.956 .951 & 325.925 .952 \\
\hline $\begin{array}{l}\text { Sociedade Empresária em Nome Co- } \\
\text { letivo }\end{array}$ & 1.421 & 8.915 & 82.596 \\
\hline $\begin{array}{l}\text { Sociedade Empresária em Comandi- } \\
\text { ta Simples }\end{array}$ & 51 & 562 & 5.777 \\
\hline $\begin{array}{l}\text { Sociedade Empresária em Comandi- } \\
\text { ta por Ações }\end{array}$ & 31 & 2.862 & 30.652 \\
\hline Sociedade em Conta de Participação & 48 & 180 & 908 \\
\hline Empresário (Individual) & 1.758 .859 & 4.556 .109 & 25.487 .810 \\
\hline Consórcio de Sociedades & 1.771 & 130.979 & 3.353 .624 \\
\hline Grupo de Sociedades & 72 & 117 & 193 \\
\hline $\begin{array}{l}\text { Estabelecimento, no Brasil, de Socie- } \\
\text { dade Estrangeira }\end{array}$ & 144 & 5.220 & 320.028 \\
\hline Empresa Domiciliada no Exterior & 155 & 125 & 354 \\
\hline Clube/Fundo de Investimento & 9.401 & 2.395 & 36 \\
\hline Sociedade Simples Pura & 22.824 & 130.856 & 1.880 .723 \\
\hline Sociedade Simples Limitada & 229.198 & 1.212 .811 & 11.806 .471 \\
\hline Sociedade Simples em Nome Coletivo & 164 & 1.022 & 21.837 \\
\hline $\begin{array}{l}\text { Sociedade Simples em Comandita } \\
\text { Simples }\end{array}$ & 16 & 48 & 221 \\
\hline Empresa Binacional & 2 & $\mathrm{x}$ & $\mathrm{x}$ \\
\hline Consórcio de Empregadores & 4 & $\mathrm{x}$ & $\mathrm{x}$ \\
\hline Empresa Individual Imobiliária & 6.107 & $\mathrm{x}$ & $\mathrm{x}$ \\
\hline Segurado Especial & 2 & $\mathrm{x}$ & $\mathrm{x}$ \\
\hline Contribuinte individual & 63.188 & 76.759 & 154.532 \\
\hline $\begin{array}{l}\text { Serviço Notarial e Registral (Cartó- } \\
\text { rio) } 5\end{array}$ & 8.125 & 45.847 & 947.120 \\
\hline Total & 4.596 .417 & 36.169 .019 & 515.604 .312 \\
\hline
\end{tabular}

Fonte: IBGE (2010).

laços, um "[...] emaranhado de contatos, alianças e estratégias gravitando em torno de interesses políticos e econômicos" existente no país, com forte presença do Estado.

17 A Lei n. 12.441, de 11 de julho de 2011, criou a Empresa Individual com Responsabilidade Ltda. (Eireli), Código Civil, art. 980-A, figura que não consta no Cadastro ora utilizado, o qual é de 2010. 
O setor privado real é bem maior do que indicam esses números: em razão da informalidade, há um considerável contingente de empresas não registradas oficialmente. Segundo o próprio IBGE (2012), entre os anos de 2001 e 2011 o grau de informalidade caiu de forma constante, oscilando de $55,1 \%$ para $45,4 \%$, uma queda registrada em todas as regiões e mais acentuada nas regiões metropolitanas. Outro estudo, o Índice de Economia Subterrânea, calculado pelo Instituto Brasileiro de Ética Concorrencial e pela Fundação Getúlio Vargas, indica que a informalidade da economia em 2011 ficou em 16,8\% do PIB, representando um valor estimado em $\mathrm{R} \$$ 695,7 bilhões, um decréscimo significativo em relação aos $21 \%$ registrado em 2003 (GUERRA, 2012).

\subsection{Terceiro setor no Brasil}

O terceiro setor formal é um conjunto heterogêneo de 512.195 entidades, com 3.520.413 pessoas ocupadas e com remuneração total de $\mathrm{R} \$ 63.220 .340 .000,00$. Terceiro em ordem de importância econômica, seus números são bem expressivos. A Tabela 3 detalha informações sobre os vários tipos de organizações.

Tabela 3 - Terceiro setor no Brasil: entidades, pessoal ocupado e remunerações

\begin{tabular}{lrrr}
\hline \multicolumn{1}{c}{ Tipo de entidade } & N. de Entidades & $\begin{array}{c}\text { Pessoal } \\
\text { ocupado }\end{array}$ & $\begin{array}{c}\text { Salários e remunera- } \\
\text { çóes (em 1.000 R\$) }\end{array}$ \\
\hline Fundação Privada & 4.849 & 297.930 & 8.130 .053 \\
Serviço Social Autônomo & 264 & 119.164 & 3.541 .939 \\
Condomínio Edifício & 148.828 & 623.346 & 6.716 .473 \\
Comissão de Conciliação Prévia & 8 & 20 & 436 \\
Entidade de Mediação e Arbitragem & 82 & 108 & 319 \\
Partido Político & 7.954 & 3.736 & 24.553 \\
Entidade Sindical & 17.427 & 132.375 & 1.631 .669 \\
Estabelecimento, no Brasil, de Funda- & 44 & 273 & 17.138 \\
ção ou Associação Estrangeiras & & & \\
Fundação ou Associação Domiciliada & 12 & 8 & 137 \\
no Exterior & & & 106.527 \\
Organização Religiosa & 4.403 & 10.342 & $\mathrm{x}$ \\
Comunidade Indígena & 4 & $\mathrm{x}$ & 36.539 .539 \\
Associação Privada & 317.389 & 1.962 .898 & 6.488 .673 \\
Cooperativa & 10.899 & 369.827 & 22.884 \\
Organização Internacional & 32 & 386 & 63.220 .340 \\
Total & 512.195 & 3.520 .413 & \\
\hline Fonte: IBGG (2010). & & &
\end{tabular}

Fonte: IBGE (2010).

As estatísticas oficiais não englobam o largo leque das organizações informais. Diferentemente da informalidade do setor privado, não há um mapeamento das redes comunitárias informais espalhadas pelo país.

Quanto às organizações formais, cabe destacar alguns segmentos importantes e sua importância para a garantia de direitos, a proteção e o bem-estar social: 
a) Instituições sem fins lucrativos e Instituições Comunitárias de Educação Superior (ICES) - Segundo o Censo da Educação Superior de 2011, há 1.106 instituições sem fins lucrativos na educação superior brasileira, equivalentes a 46,8\% do total das 2.365 instituições do país. Nelas, estudam 2.416.671 estudantes de graduação, o que corresponde a 35,85\% do total dos universitários brasileiros. Parcela dessas instituições, as comunitárias, inscrevem-se na larga tradição da educação comunitária, que inicia com as escolas católicas no início da colonização, passa por experiências como as escolas comunitárias das regiões de colonização europeia nos Estados do Sul, as escolas cenecistas e as universidades comunitárias (SCHMIDT, 2009, 2010, 2012). As instituições sem fins lucrativos são consideradas legalmente uma categoria das instituições privadas, conforme prevê a Lei de Diretrizes e Bases da Educação (Lei 9.394/1996 - art. 19 e 20). As instituições comunitárias conquistaram um marco legal próprio, através de Lei 12.881/2013, que criou a figura jurídica das Instituições Comunitárias de Educação Superior, uma modalidade distinta das instituições privadas. Essa lei contém elementos para um novo tratamento jurídico do terceiro setor.

b) Hospitais comunitários e filantrópicos - Estão presentes no país desde o início da colonização, sendo o principal espaço de atendimento aos doentes desde a colonização do país até a estruturação do sistema público ao longo do século passado. Em muitos municípios pequenos continuam sendo o único espaço de atendimento hospitalar. Atualmente, existem 2.100 desses hospitais no país, metade dos quais está em pequenos municípios, com um total de 175 mil leitos (34\%), mas nos quais acontecem $45 \%$ das internações do Sistema Único de Saúde, do qual são parceiros fundamentais (CASTRO, 2012).

c) Cooperativas - Segundo a Tabela 3, há 10.899 cooperativas no país, nas quais trabalham 369.827 pessoas, com remunerações de $R \$$ 6.488.673.000,00. Conforme o Censo do Cooperativismo Brasileiro de 2007, a maioria (mais de 7.600 cooperativas) está filiada ao sistema da Organização das Cooperativas do Brasil, cujo faturamento alcança U\$ 41 bilhões (NINAUT; MATOS, 2008).

d) Clubes esportivos - Há um elevado contingente de clubes esportivos em todas as regiões do país. O Cadastro Nacional de Clubes de Futebol, elaborado pela Confederação Brasileira de Futebol (2009), mostra que há aproximadamente 780 clubes de futebol profissional no Brasil. Parte significativa desses clubes pertence a um coletivo de associados e a comunidades. Segundo estimativa da Institutional Business Consultoria Internacional, o esporte representa $1,9 \%$ do PIB brasileiro, cerca de $\mathrm{R} \$$ 50 bilhões em 2008, e emprega mais de 1 milhão de pessoas, entre em- 
pregos diretos e indiretos. Incluindo no cálculo os impostos arrecadados pelo setor, a representatividade econômica do segmento atinge $2,2 \%$ (SOMOGGI, 2009).

e) Sindicatos - Há 17.412 entidades sindicais no país, nas quais trabalham 134.970 pessoas, conforme a Tabela 3. Os sindicatos são, com as cooperativas, exemplos históricos da ação comunitária em defesa de interesse dos trabalhadores. Apesar das dificuldades que enfrentam, sua ação mantém-se imprescindível para reduzir as disparidades do mundo do trabalho.

f) Rádios e TVs comunitárias - O país conta com 4.556 emissoras comunitárias (rádios e TVs) aprovadas, além de milhares de pedidos encaminhados, conforme o Ministério das Comunicações (2014). Essas emissoras são mantidas por organizações sociais e estão amparadas no art. 223 da Constituição Federal e na Lei da Radiodifusão Comunitária (Lei n. 9.612/1998).

g) Bancos comunitários - São serviços financeiros e bancários gerenciados pelas próprias comunidades, voltados à população em situação de vulnerabilidade social. Trata-se de uma experiência popular em fase de expansão em várias regiões do país, havendo atualmente mais de 50 instituições, reunidas na Rede de Bancos Comunitários. Os bancos comunitários são criados e geridos por comunidades, mediante uma associação local, proporcionam financiamento da produção e do consumo local, visam ao fomento do desenvolvimento do comércio local e da economia popular, e atuam em territórios caracterizados pelo alto grau de exclusão social (BANCO PALMAS, 2012).

\subsection{Representatividade econômica dos setores}

Os dados do Cadastro Geral de Empresas 2010 acerca do setor público, do setor privado e do terceiro setor, apresentados anteriormente, permitem dimensionar a participação de cada qual na economia formal. A Tabela 4 sintetiza os dados.

Tabela 4 - Representatividade econômica do setor público, do setor privado e do terceiro setor

\begin{tabular}{lrrrrrr}
\hline & $\begin{array}{c}\text { N. de órgãos, } \\
\text { empresas e } \\
\text { entidades }\end{array}$ & $\%$ & $\begin{array}{c}\text { Pessoal ocupa- } \\
\text { do total }\end{array}$ & $\%$ & \multicolumn{2}{c}{$\begin{array}{c}\text { Salários e remu- } \\
\text { neraçóes (em R\$ } \\
\mathbf{1 . 0 0 0 , 0 0 )}\end{array}$} \\
\hline Setor público & 19.958 & 0,4 & 10.005 .817 & 20,1 & 326.691 .854 & 36,1 \\
Setor privado & 4.596 .415 & 89,6 & 36.169 .019 & 72,8 & 515.604 .312 & 56,9 \\
Terceiro setor & 512.195 & 10 & 3.520 .413 & 7,1 & 63.220 .340 & 7 \\
Total & 5.128 .568 & 100 & 49.695 .249 & 100 & $905.516 .506,00$ & 100 \\
\hline
\end{tabular}

Fonte: IBGE (2010). 
O setor público é pouco expressivo do ponto de vista do número de organizações do país - apenas $0,4 \%$ do total -, mas importante em termos de pessoal ocupado - 20,1\% - e mais ainda, em termos de salários e remunerações - 36,1\%.

O setor privado é o maior setor em todos os aspectos: 89,6\% das organizações do país são privadas e $72,8 \%$ do pessoal ocupado atua no setor privado, cujos salários e remunerações alcançam 56,9\% do total.

O terceiro setor tem uma representatividade bastante considerável: participa com $10 \%$ das organizações, $7,1 \%$ do pessoal ocupado e $7 \%$ dos salários e remunerações.

Esse dimensionamento da representatividade econômica dos setores é um recorte parcial e aproximativo. Mas traz elementos valiosos para avaliar a questão do equilíbrio Estado-comunidade-mercado no Brasil, auxilia na análise de tendências e inovações sociopolíticas, na perspectiva da ação sinérgica entre os setores público, privado e terceiro setor.

\section{Conclusão}

As organizações comunitárias e sociais, componentes fundamentais das sociedades de hoje, são cada vez mais diversificadas e não se enquadram nos esquemas simplistas próprios da divisão público/privado. Essa dicotomia tem levado à confusão entre mercado e terceiro setor e entre organizações privadas e organizações comunitárias, confusão que ainda vige na cultura política e jurídica brasileira e que deve ser superada. O tripé Estado/comunidade/mercado e os conceitos correspondentes de público/comunitário/privado permitem uma compreensão mais apropriada da dinâmica social de nossos dias e abrem caminho para importantes inovações sociopolíticas.

A retomada do sentido original do público - aquilo que é de todos, do povo, do coletivo - supera a indevida equivalência entre público e estatal, pois o público abrange formas estatais e não estatais. Privado diz respeito ao indivíduo, à família, ao particular, e seu território principal, em termos econômicos, é o mercado. A meio caminho, o comunitário, terreno do bem comum, do coletivo, do público não estatal. Tal reconceitualização é condizente com a perspectiva comunitarista do equilíbrio Estado-comunidade-mercado, que não é uma fórmula rígida e única para todos os países, mas uma diretriz geral para explicar as dinâmicas sociais das sociedades atuais, em que o público, o comunitário e o privado são distintos e inter-relacionados, cada qual com fortalezas e fragilidades. A hipertrofia de algum dos setores desiquilibra o tripé.

Os dados do Cadastro Geral de Empresas 2010 examinados indicam que o setor privado é majoritário no Brasil tanto do ponto de vista do número de organizações quanto do pessoal ocupado e dos salários e remunerações pagas na economia formal; que o setor público tem um percentual baixo do total das organizações, mas é expressivo em termos de pessoal ocupado e, especialmente, de salários e remune- 
rações pagos; e que o terceiro setor tem participação minoritária, mas significativa: $10 \%$ das organizações e $7 \%$ do pessoal ocupado e das remunerações.

Comunidade forte rima com Estado forte e com mercado dinâmico. A presença histórica das organizações comunitárias em setores vitais, como a educação e a saúde e o crescimento do terceiro setor nas últimas décadas mostram que o país conta com condições objetivas para caminhar rumo a um maior equilíbrio entre Estado, comunidade e mercado.

\section{Referências}

ALENCASTRO, Luiz Felipe. Vida privada e ordem privada no Império. In: NOVAIS, F.; ALENCASTRO, L. Felipe. (Coord.) História da vida privada no Brasil: Império. São Paulo: Cia das Letras, 1997.

ARENDT, Hannah. A condição humana. 6. ed. Rio de Janeiro: Forense Universitária, 1993.

BAQUERO, Marcello; CREMONESE, Dejalma (Org.). Capital social: teoria e prática. Ijuí: Ed. Unijuí, 2006.

BANCO PALMAS. Disponível em: < http://www.bancopalmas.org.br > . Acesso em: 15 jul. 2012.

BARBER, Benjamin. Un lugar para todos: como fortalecer la democracia y la sociedad civil. Barcelona: Paidós Ibérica, 2000.

BIASCO, Emilio. Las personas publicas no estatales e paraestatales. 2010. Disponível em: < http://www.ccee.edu.uy/ensenian/catderpu/material/paraesta.PDF>. Acesso em: 17 jul. 2012.

BOBBIO, Norberto. Estado, governo, sociedade: para uma teoria geral da política. 14. ed. São Paulo: Paz e Terra, 2007.

BRAGA NETTO, Felipe Peixoto. Os sistemas duais e sua crise: o fim das grandes certezas. Revista Direitos e Deveres, Alagoas, v. 2, n. 5, p. 115-132, jul./dez. 1999.

BRASIL. Ministério das Comunicações. Radiodifusão comunitária. 27 jun. 2012. Disponível em: < http://www.mc.gov.br/numero-de-emissoras-comunitarias-no-pais >. Acesso em: 30 mar. 2014.

BRASIL. Ministério do Planejamento, Orçamento e Gestão. Perfil das empresas estatais federais 2010. Brasília, DF: MP/ SE/ DEST, 2011.

BRESSER-PEREIRA, Luis Carlos; CUNILL GRAU, Nuria (Org.). O público não-estatal na reforma do estado. Rio de Janeiro: FGV, 1999. 
BUBER, Martin. Caminos de utopía. México: Fondo de Cultura Economica, 2006.

CANO, José María Sauca; SIMON, María Isabel Wences. Lecturas de la sociedade civil: um mapa contemporâneo de sus teorias. Madrid: Trotta, 2007.

CARVALHO, José Murilo de. Cidadania no Brasil: o longo caminho. Rio de Janeiro: Civilização Brasileira, 2001.

CASTRO, Grasielle. Santas Casas do país pedem misericórdia. Correio Braziliense, 22 jul. 2012, p. 12.

CHACON, Vamireh. Cooperativismo e comunitarismo. Belo Horizonte: UFMG, 1959.

COHEN, Jean; ARATO, Andrew. Sociedad civil y teoria política. México: Fondo de Cultura Económica, 2000.

CONFEDERAÇÃO BRASILEIRA DE FUTEBOL. Cadastro Nacional de Clubes de Futebol. 2009. Disponível em: <http://www.cbf.com.br/media/364664/cncf\%202009. pdf > . Acesso em: 03 maio 2012.

CUNNIL GRAU, Nuria. Repensando o público através da sociedade: novas formas de gestão pública e representação social. Rio de Janeiro: Revan; Brasília: ENAP, 1998.

DEWEY, John. La opinión pública y sus problemas. Madrid: Morata, 2004.

ESPING-ANDERSEN, Gosta. O futuro do welfare state na nova ordem mundial. Lua Nova, São Paulo n. 35, 1995, p. 73-111, 1995.

ETZIONI, Amitai. La dimensión moral: hacia una nueva economía. Madrid: Astor Juvenil Palabra, 2007.

ETZIONI, Amitai. La nueva regla de oro: comunidad y moralidad en uma sociedad democrática. Barcelona: Paidós Ibérica, 1999.

ETZIONI, Amitai. La tercera vía hacia una buena sociedad: propuestas desde el comunitarismo. Madrid: Minima Trotta, 2001a.

ETZIONI, Amitai. Los limites de la privacidad. Madrid, Buenos Aires e Montevideo: Edisoffer e BdeF, 2012.

ETZIONI, Amitai. Organizações modernas. São Paulo: Pioneira, 1976.

ETZIONI, Amitai. The monochrome society. Princeton and Oxford: Princeton University Press, 2001b. 
EVANS, Peter. Análise do Estado no mundo neoliberal: uma abordagem institucional comparativa. Revista de Economia Contemporânea, n. 4, p. 51-85, jul./dez. 1998.

FAORO, Raimundo. Os donos do poder. 3. ed. Rio de Janeiro: Globo, 1976.

GENRO, Tarso. Utopia possível. Porto Alegre: Artes e Ofícios, 1995.

GOBETTI, Sergio Wulff. Estatais e ajuste fiscal: uma análise da contribuição das empresas federais para o equilíbrio macroeconômico. Economia e Sociedade, Campinas, v. 19, n. 1, p. 29-58, abr. 2010.

GÓMEZ, Manuel Herrera; BOYER, Pedro Castón. Las políticas sociales en las sociedades complejas. Madrid: Ariel, 2003.

GUERRA, Giane. Mercado de trabalho reduz economia informal no Brasil. Acerto de Contas, Click RBS, 04 jul. 2012. Disponível em: < http://wp.clicrbs.com.br/acertodecontas/2012/07/04/mercado-de-trabalho-reduz-economia-informal-no-brasil/>. Acesso em: 12 jun. 2013.

HABERMAS, Jürgen. Mudança estrutural da esfera pública: investigações quanto a uma categoria da sociedade burguesa. Rio de Janeiro: Tempo Brasileiro, 1984.

INSTITUTO BRASILEIRO DE GEOGRAFIA E ESTATÍSTICA. Cadastro Central de Empresas 2010. Rio de Janeiro: IBGE, 2010.

INSTITUTO BRASILEIRO DE GEOGRAFIA E ESTATÍSTICA. Estatísticas do Cadastro Central de Empresas 2010. IBGE: Rio de Janeiro, 2012.

IBGE; IPEA; ABONG; GIFE. As fundações privadas e associações sem fins lucrativos no Brasil 2005. Rio de Janeiro: IBGE, 2008.

INSTITUTO NACIONAL DE ESTUDOS E PESQUISAS EDUCACIONAIS ANÍSIO TEIXEIRA. Censo da Educação Superior de 2011. Brasília: INEP, 2012.

INGLEHART, Ronald; WELZEL, Christian. Modernização, mudança cultural e democracia: a sequência do desenvolvimento humano. São Paulo: Francis, 2009.

INSTITUTO DE PESQUISA ECONÔMICA APLICADA. Emprego público no Brasil: comparação internacional e evolução recente. Brasília, 2009.

INSTITUTO DE PESQUISA ECONÔMICA APLICADA. Presença do Estado no Brasil: Federação, suas unidades e municipalidades. Brasília, 2009. Disponível em: <http://www.ipea.gov.br/presenca/images/presenca_web_2aed.pdf > . Acesso em: 30 jun. 2013. 
INSTITUTO DE PESQUISA ECONÔMICA APLICADA . PNAD 2011: primeiras análises sobre o mercado de trabalho brasileiro. Comunicados do IPEA n. 156. Brasília: IPEA, 2012. Disponível em: <www.ipea.gov.br>. Acesso em: 28 out. 2013.

LAZZARINI, Sérgio Giovanetti. Capitalismo de laços: os donos do Brasil e suas conexões. Rio de Janeiro: Elsevier e Campus, 2011.

LINDBLOM, Charles. El sistema de mercado. Madrid: Alianza Editorial, 2002.

MACIEL, Vladimir; ARVATE, Paulo. Tamanho do governo brasileiro: conceitos e medidas. RAC, Curitiba, v. 14, n. 1, art. 1, p. 1-19, jan./fev. 2010.

MALLARDI, Manuel Waldemar. Las organizaciones públicas no estatales (OPNES) en la producción de servicios sociales. In: CONFERENCIA REGIONAL DE ISTR PARA AMÉRICA LATINA Y EL CARIBE, 6., 2007, Salvador. Anais... Salvador, 2007. Disponível em: <http://socunicen.academia.edu/ManuelMallardi/Papers/1271955>. Acesso em: 17 jul. 2013.

MARX, Karl; ENGELS, Friedrich. La ideología alemana. Buenos Aires: Pueblos Unidos y Editorial Cartago, 1985.

NÁUFEL, José. Novo dicionário jurídico brasileiro. 11. ed. Rio de Janeiro: Forense, 2008.

NINAUT, Evando Scheid; MATOS, Marcos Antonio. Panorama do cooperativismo no Brasil: censo, exportações e faturamento. Informações Econômicas, São Paulo, v. 38 , n. 8, p. 43-55, ago. 2008.

NISBET, Robert. Comunidade. In: FORACCHI, M. M.; MARTINS, J. S. (Org.). Sociologia e sociedade: leituras de introdução à sociologia. Rio de Janeiro: LTC, 1998.

NISBET, Robert. Os filósofos sociais. Brasília: Edunb, 1982.

PARSONS, Wayne. Public policy: an introduction to the theory and practice of policy analysis. Cheltenham and Northampton: Edward Elgar Publishing, 2003.

PATEMAN, Carole. Críticas feministas a la dicotomia público/privado. In: CASTELLS, Carmen (Org.). Perspectivas feministas en teoría política. Barcelona: Paidós, 1996.

POLANYI, Karl. A grande transformação. Rio de Janeiro: Campus, 2000.

PUTNAM, Robert. Comunidade e democracia: a experiência da Itália Moderna. Rio de Janeiro: Ed. Getúlio Vargas, 1996. 
RABOTNIKOF, Nora. Público-privado. Debate Feminista, ano 9, v. 18, p. 1-11, out. 1998. Disponível em: < http://www.debatefeminista.com/PDF/Articulos/public410. pdf $>$. Acesso em: 23 jul. 2013.

RABOTNIKOF, Nora. Lo público y sus problemas: notas para una reconsideración. Revista Internacional de Filosofia Política, v. 2, 1993. Disponível em: < http:// pt.scribd.com/doc/39005493/Lo-Publico-y-Sus-Problemas >. Acesso em: 23 jul. 2013.

REIS, Jorge Renato dos; CERQUEIRA, Katia Leão. Intersecções jurídicas entre o público e o privado: uma abordagem principiológica constitucional. Salvador: Edufba, 2012.

RESTA, Eligio. O direito fraterno. Santa Cruz do Sul: Edunisc, 2004.

REZENDE, Flavio da Cunha. Gastos públicos e mudanças recentes no papel do estado: uma análise comparada entre países desenvolvidos e em desenvolvimento. Novos Estudos CEBRAP, São Paulo, v. 62, p. 123-139, mar. 2002.

SACHS, Jeffrey. O fim da pobreza: como acabar com a miséria mundial nos próximos 20 anos. São Paulo: Cia das Letras, 2005.

SANDEL, Michael. O que o dinheiro não compra: os limites morais do mercado. Rio de Janeiro: Civilização Brasileira, 2012.

SANTOS, Wanderley Guilherme dos. O ex-leviatã brasileiro: do voto disperso ao clientelismo concentrado. Rio de Janeiro: Civilização Brasileira, 2006.

SARMENTO, Daniel. Interesses públicos vs. Interesses privados na perspectiva da teoria e da filosofia constitucional. In: SARMENTO, D. (Org.). Interesses públicos versus interesses privados: desconstruindo o princípio de supremacia do interesse público. Rio de Janeiro: Lumen Juris, 2007.

SCHMIDT, João Pedro. Università 'comunitarie' brasiliane: um'innovazione istituzionale in cerca di adeguato inquadramento giuridico. Istituzioni del Federalismo Rivista di studi giuridici e politici, v. 33, p. 443-460, 2012.

SCHMIDT, João Pedro; ARAUJO, Neiva. Comunidade e comunitarismo na Constituição Federal e na legislação brasileira. Novos Estudos Jurídicos, v. 17, n. 3, p. 327344, set./dez. 2012a. Disponível em: < http://siaiweb06.univali.br/seer/index.php/nej/ article/view/4203>. Acesso em: 17 dez. 2012.

SCHMIDT, João Pedro. Comunidade e comunitarismo: considerações sobre a inovação da ordem sociopolítica. Ciências Sociais Unisinos, São Leopoldo, v. 47, n. 3, p. 300-313, set./dez. 2011.

SCHMIDT, João Pedro. O comunitário em tempos de público não estatal. Avaliação, Campinas; Sorocaba, v. 15, n. 1, p. 9-40, mar. 2010. 
SCHMIDT, João Pedro. Instituições comunitárias: instituições públicas não estatais. Santa Cruz do Sul: Edunisc, 2009.

SIDOU, José Maria Othon. Dicionário jurídico da academia brasileira de letras jurídicas. 3. ed. Rio de Janeiro: Forense Universitária, 1995.

SILVA, De Plácido. Vocabulário jurídico. Rio de Janeiro: Forense, 2000.

SOMOGGI, Amir. O PIB do esporte no Brasil. América Economia, 29 jul. 2009.

Disponível em: <http://www.sapesp.com.br/arquivos/imprimir.php? noticia=246>. Acesso em: 05 out. 2012.

SPENGLER, Fabiana. Fundamentos políticos da mediação comunitária. Ijuí: Ed. Unijuí, 2012.

SUBIRATS, Joan et al. Análisis y gestión de políticas públicas. Barcelona: Planeta, 2012.

TÖNNIES, Ferdinand. Comunidad y asociación. Granada: Comares, 2009.

VIEIRA, Liszt. Os argonautas da cidadania. São Paulo: Record, 2001.

WEBER, Max. Economia e sociedade. 3. ed. Brasília: Edunb, 1994.

Data da submissão: 01 de abril de 2014 Avaliado em: 16 de junho de 2014 (Avaliador A) Avaliado em: 24 de agosto de 2014 (Avaliador B) Aceito em: 25 de março de 2015 